\title{
Analysis of ethnic differences of Iranian sports fans in the variables of Islamic cohesion, national identity, and perception of sports success
}

\section{Análisis de las diferencias étnicas de los aficionados al deporte iraníes en las variables de cohesión islámica, identidad nacional y percepción del éxito deportivo}

\author{
Amir Hossein Monazzami \\ Assist. Prof., Department of Sport Management, Faculty of Sport Sciences, Shahid \\ Rajaee University, IRAN \\ ORCID ID:https://orcid.org/0000-0002-8020-7698 \\ Behnam Naghi-Pour Givi \\ Assist. Prof., Sport Sciences Research Institute of Iran, IRAN \\ ORCID ID:https://orcid.org/0000-0003-0637-2086
}

*Correspondence

Email: Behnam.naghipour@gmail.com
Cite as:

Monazzami, A.H., \& Naghi-pour, B. (2021). Analysis of ethnic differences of Iranian sports fans in the variables of Islamic cohesion, national identity, and perception of sports success. Propósitos y Representaciones, 9 (SPE3), e1112.

Doi: http://dx.doi.org.10.20511.pyr2021.v9nSPE3.1112 


\section{Summary}

Iran is a country with different ethnicities and religions and some negative experiences of conflicts throughout history. It is believed that; Sports success is a factor in the greater convergence of a country's citizens. This article analyzes the ethnic differences of Iranian sports fans in Islamic cohesion, national identity, and perception of sports success. The research was a descriptive survey. The statistical population was all Iranians interested in national sports, 968 of whom participated in the study voluntarily. The research instruments were the researcher-made questionnaire of Perception of Sports Success, the National Identity Questionnaire of Hear and James (2007), and the Islamic Cohesion Questionnaire of Baghbanian and Morowat (2011). The content and face validity of the questionnaires were confirmed by the professors and their reliability was calculated with Cronbach's alpha coefficient of $0.78,0.88$, and 0.83 , respectively. The test of hypotheses showed that; the variables of Islamic cohesion and national identity have a statistically significant difference between Shiite and Sunni respondents $(\mathrm{P}<0.05)$. The variables of Islamic cohesion and national identity also had a statistically significant difference between the respondents of ethnic groups $(\mathrm{P}<0.05)$ while there was no statistically significant difference in the perception of sporting success between the respondents of different ethnic groups and religious groups $(\mathrm{P}<0.05)$. The findings of the study emphasized the positive functions of sports success in the convergence of more religious and ethnic groups in the country.

Keywords: Sports success, national convergence, Iranian ethnic groups.

\section{Resumen}

Irán es un país con diferentes etnias y religiones y algunas experiencias negativas de conflictos a lo largo de la historia. Se cree que; El éxito deportivo es un factor en la mayor convergencia de los ciudadanos de un país. Este artículo analiza las diferencias étnicas de los aficionados al deporte iraníes en la cohesión islámica, la identidad nacional y la percepción del éxito deportivo. La investigación fue una encuesta descriptiva. La población estadística fue de todos los iraníes interesados en los deportes nacionales, 968 de los cuales participaron en el estudio de forma voluntaria. Los instrumentos de investigación fueron el cuestionario elaborado por investigadores de Perception of Sports Success, el Cuestionario de Identidad Nacional de Hear y James (2007), y el Cuestionario de Cohesión Islámica de Baghbanian y Morowat (2011). El contenido y la validez aparente de los cuestionarios fueron confirmados por los profesores y su confiabilidad se calculó con el coeficiente alfa de Cronbach de 0,78, 0,88 y 0,83, respectivamente. La prueba de hipótesis mostró que; las variables de cohesión islámica e identidad nacional tienen una diferencia estadísticamente significativa entre los encuestados chiítas y sunitas $(\mathrm{P}<0,05)$. Las variables de cohesión islámica e identidad nacional también tuvieron una diferencia estadísticamente significativa entre los encuestados de grupos étnicos $(\mathrm{P}<0.05)$ mientras que no hubo diferencia estadísticamente significativa en la percepción del éxito deportivo entre los encuestados de diferentes grupos étnicos y grupos religiosos $(\mathrm{P}<0,05)$. Los hallazgos del estudio enfatizaron las funciones positivas del éxito deportivo en la convergencia de más grupos étnicos y religiosos en el país.

Palabras clave: Éxito deportivo, convergencia nacional, etnias iraníes.

\section{Introduction}

One of the most important aspects of human populations is their heterogeneity. According to some theories, the world's population includes 6,000 languages and approximately 5,000 different ethnic groups. Our country, Iran, is also a multi-ethnic community and in terms of ethnic and cultural diversity index, it is ranked second among 19 countries in the Middle East and North Africa and twenty-eighth among 160 countries in the world (Abbasi Shavazi and Hosseini, 2007: $5)$. There are no specific statistics on the number and proportion of Iranian ethnic groups and the 
Statistics Center of Iran, which is responsible for providing accurate and official statistics, for unknown reasons, does not provide clear statistics in this regard. Therefore, the statistics and figures expressed in various sources are mainly estimates and cannot be conclusively accepted (Matlabi, 2008: 16). In some sources, the majority group (Persians) makes up only $46.2 \%$ of the total population. In addition to the Persians; other ethnic groups such as Kurds, Turks, Lors, Baluchis, Arabs, Turkmen, etc. also live in Iran, each of which has a different share of the total population of Iran. Although each non-Persian ethnic group has a smaller share of the total population than the Persian majority, the population of ethnic groups as a whole is larger than the majority of Persians (Abbasi Shavazi and Hosseini, 2007: 5). Ethnicity is a social organization formed on the territory of certain land and includes people who have established economic, cultural, kinship, etc. ties throughout history and have a common language, cultural, religious, and religious characteristics, blood ties, customs, traditions, and social values. Ethnicity also belongs to an ethnic group that includes awareness of historical roots and historical traditions and common traditions and is a complex combination of cultural, racial, and historical characteristics and when self-awareness is included in this definition, it becomes ethnic. Ethnicity is a very common mental model according to which each person considers his own culture as the best existing culture and judge the values of other communities based on its internalized social values. It also tends to issue value judgments about other cultures and societies that are associated with overall superiority. It is on this basis that their collective identity is formed and it is sometimes referred to as ethnic nationalism (Moeidfar and Rezaei, 2009: 17).

Identity is essentially a two-dimensional concept that implies both differences and similarities. Identity is one of the psychological needs of human beings and a prerequisite for any social life. Without a framework for social identification, individuals will be alike and none of them can relate to others in a meaningful and lasting way. The basis of the survival of human society is the social identity of that society and the result of the process of interaction between the individual and the social field. Also, identity is not only an element of individual character but also a dimension of social relationships that are realized in expression. In this regard, identity is the result of the interaction of the individual and society in the form of a complex matter. The social dimension of identity is important in that; Introduces family, nationality, race, employment, etc. as assets of individual origin. One of the most important and noteworthy issues in any society is the relationship between different and numerous identities within the society with the national and general identity that connects these cultures. In such a way that the incoherence between these identities causes the actor to experience a different process of socialization and have problems in terms of social cohesion (Misrabadi, Yar Mohammadzadeh, and Faizi, 2015: 29).

National identity is the most important dimension of social identity. Social identity refers to the membership of social groups (Kiakjuri, 2007: 98). National identity means a sense of belonging and loyalty to common elements and symbols in the national community (the whole society) and within defined political boundaries. The most important elements and national symbols that cause identification and differentiation are Lands, religion, customs, history, language and literature, people, and government (Yousefi, 2001: 15). According to McKenzie, national identity is one of the four types of identity that have survived since the 19th century and along with the other three types, there is a religious, class, and racial identity. Some definitions of national identity emphasize the unifying elements of an independent political unit and define it as a set of positive tendencies and attitudes towards the identifying and unifying factors and elements and patterns at the level of a country as a political unit (Hajiani, 2000: 195). It seems that the national identity of Iranians is a complex category that is influenced by many variables. The main elements and symbols that form the national identity of individuals in Iranian society and have been mentioned by most researches in Iran include National language and literature (Persian), the religion of Islam, cultural and social figures of the country, national geography, and national government (political dimension) (Mohammad Bakhsh, Hobi, and Qureshi, 2011: 14).

The composition of Iran's population is such that the reference to a multi-ethnic society is not far from reality. The presence and life of different ethnicities such as Persians, Turks, Kurds, Lors, Baluchis, Turkmens, and Arabs next to each other and within the framework of single political geography show the ethnic-cultural diversity of Iranian society. Different inhabitants of modern Iran have been a heterogeneous collection of different racial, linguistic, religious, and cultural 
ethnicities. In some periods of their common history in Iran, they have not had the necessary social cohesion and homogeneity. For this reason, the seeds of the identity crisis have been present mainly in them, which have become aspects of a political crisis at certain times; like what has happened in Azerbaijan, Kurdistan, Turkmen Sahara, etc (Moeidfar and Rezaei, 12009: 14). In other words, we can say: Given that Iran is one of the most populous countries in the world. Therefore, inter-ethnic relations and political-cultural conflicts and challenges have been inevitable. On the other hand, the level of human development in Iran is equal to that of developing countries, and historically, ethnic conflict has been one of the most important challenges for the central government to improve security and development and reduce distributional disruption and sectorial inequalities (Mohammad Bakhsh, Hobi, and Qureshi, 2011: 30).

As mentioned, several elements have played a role in shaping the national identity of Iranians over time. Persian language and Islam are two of the most important ones; in particular, the role of Islam and religious identity in the convergence of Iranian ethnic groups is undeniable. The passage of time and the entry into the modern age have not diminished the importance of identifying elements such as language and religion. In addition to these elements, new symbols have emerged that can lead to greater convergence of ethnic groups under the umbrella of national identity. Sport is one of the most important new symbols of identity, as a complex social whole, it is closely related to social rituals and events and has been emphasized in various domestic and foreign researches. Ahmadi (2007) showed the diminishing effect of the defeat of the Iranian national football team against Mexico and Portugal on the national identity of the citizens of Yasuji in the 2006 World Cup. Ahmadpour, Khabiri, and Rajabi (2017) state that Sport can strengthen national solidarity and by creating national pride and tying the interests of different groups of society, it will cause solidarity and harmony within the country and show power in the international arena. Kersting (2007) by examining the different trends during the 2006 and 2010 World Cups in the two time periods before and after the games has shown that; National pride has risen significantly during the World Cup in Germany and although it has declined again since the end of the World Cup, it is still higher than before the tournament. In a 2006 study of German citizens, Hallmann, Breuer, and Kühnreich (2013) showed that; Overall, 66.2\% of respondents were proud and $65.6 \%$ were happy with the success of German athletes in major sporting events. Elling, Van Hilvoorde, and Van Den Dool (2014) ran a total of 11,185 people between 2008 and 2010, when the 2010 FIFA World Cup in South Africa, the 2008 Beijing Summer Olympics, and the 2010 Vancouver Winter Olympics were played. Dutch citizens over the age of 18 conducted a study, the results of this study showed that; overall, $54.2 \%$ of Dutch people have very high national pride, $75.2 \%$ of them have sporting pride, Also, during the events, sports pride and national pride of the Dutch showed a significant increase.

According to what has happened, Iran is made up of different ethnic groups that have sometimes experienced some identity crises and ethnic conflicts and conflicts throughout history which can act as a factor undermining national identity. On the other hand, in the last century and with the emergence of the phenomenon of sports in its current form, the grounds for the formation of a new element of identity for Iranians have been created. The numerous successes of national teams in various sports and the emergence of well-known and prominent athletes from different ethnic groups living in Iran who represent the single Iranian identity in international arenas can increase the national pride of Iranians and strengthen their national integration. Therefore, it seems that the perception of different Iranian ethnic groups about the success of national sports is a variable that is less affected by the ethnicity of Iranians while national identity based on its traditional elements and Islamic cohesion (which may be influenced by religious differences) may have more variability between different ethnic groups. Therefore, the present study seeks to analyze the ethnic differences of Iranian sports fans in the variables of Islamic cohesion, national identity, and perception of sports success to show the variability of each of them between different ethnic groups.

\section{Methodology}


The present study was applied in terms of purpose and descriptive-survey that was conducted in the field. The statistical population of the study was all Iranian citizens living in a country of different ethnicities, who are interested in national sports in the international arena. The criteria for identifying an interest in national sports were self-expression and voluntary participation in research. Given that it is not easy to consider a specific number for the above statistical community and a large number of citizens across the country are interested in sports and the success of national teams in the international arena. Therefore, the size of the statistical population was considered unknown. To cover as many people interested in participating in the research and according to the epidemic of coronary heart disease in different parts of the country, questionnaires were designed online and information was provided on various sites, channels, and pages so that people could voluntarily complete it. With this method and in 45 days, 1037 questionnaires were completed which 968 healthy questionnaires were entered into the analysis process by reviewing the completed questionnaires.

Research tool: three researcher-made questionnaires on sports success perception with 9 items The standard questionnaire of the national identity of Hear and James (2007) with 19 items in the form of 6 components of general evaluation, personal evaluation, sense of belonging with compatriots, interdependence, increasing participation, awareness of national identity and the standard questionnaire of Islamic cohesion of Morowat and Baghbanian (2011) with 12 questions in the form of 3 components of religious solidarity, sense of belonging to a religion and religious pride. The first questionnaire was designed based on the opinions of experts and its face and content validity was approved by 8 professors. The second questionnaire has been used and localized many times in various domestic researches, in this study; its validity was confirmed by professors. The third questionnaire, which was a native tool for Iranian respondents, and therefore its validity, is confirmed. The reliability of all three questionnaires was calculated by analyzing the initial implementation data using Cronbach's alpha coefficient of $0.78,0.88$, and 0.83 , respectively.

\section{Results}

Respondents answered various demographic questions such as age, gender, education, etc. But the most important demographic variables were ethnicity and religion, the results of which are presented in Tables 1 and 2 .

Table 1. Description of the respondents' ethnicity variable

\begin{tabular}{|l|l|l|l|}
\hline nationality & Frequency & Frequency percent & Valid frequency percentage \\
\hline Fars & 248 & 25.6 & 25.8 \\
\hline Turkish & 268 & 27.7 & 27.9 \\
\hline Kord & 107 & 11.1 & 11.1 \\
\hline Lor & 152 & 15.7 & 15.8 \\
\hline lak & 62 & 6.4 & 6.4 \\
\hline arab & 47 & 4.9 & 4.9 \\
\hline tat & 10 & 1.0 & 1.0 \\
\hline Other & 68 & 7.0 & 7.1 \\
\hline unanswered & 6 & 0.6 & - \\
\hline Total & 968 & 100 & - \\
\hline
\end{tabular}

According to Table 1, 27.9\% of the respondents are of Turkish ethnicity and $25.8 \%$ of Persian ethnicity is the most respondents, also, paying attention to the table below shows that it is interesting that $7.1 \%$ of the respondents do not consider themselves as belonging to the main ethnic groups of the country and prefer the other option. 
Table 2. Description of respondents' religion variable

\begin{tabular}{|l|l|l|l|}
\hline Religion & Frequency & Frequency percent & Valid frequency percentage \\
\hline Shia & 889 & 91.8 & 92.3 \\
\hline Sunni & 62 & 6.4 & 6.4 \\
\hline Muslim & 12 & 1.2 & 1.2 \\
\hline unanswered & 5 & 0.5 & - \\
\hline Total & 968 & 100 & - \\
\hline
\end{tabular}

According to Table 2,91.8\% of the subjects are Shiites and 6.4\% are Sunnis. The interesting thing about the religion variable is that; $1.2 \%$ of the subjects preferred to introduce themselves as Muslims and not express their religious inclinations.

Also, the description of the status of the research variables based on the religion variable is presented in Table 3. According to the table, all three variables in the two religious groups, Shia and Sunni, and in general have averages above three, but the perception of sports success is a variable that has averages above 4 . Another important point is that the variability of sports success perception scores from Shiite respondents to Sunni respondents is only 0.08 while in the other two variables; this variability is 0.33 for national identity and 0.36 for Islamic cohesion. That is the variable of perception of sports success as a phenomenon to which Iranians, regardless of religion, are more attached.

Table 3. Description of research variables based on respondents' religion variable

\begin{tabular}{|l|l|l|l|l|l|l|}
\hline Variable & \multicolumn{4}{|l|}{ Total } & Shia & Sunni \\
\cline { 2 - 7 } & Mean & SD & Mean & SD & Mean & SD \\
\hline $\begin{array}{l}\text { Perception of sports } \\
\text { success }\end{array}$ & 4.16 & 0.624 & 4.17 & 0.612 & 4.09 & 0.671 \\
\hline National identity & 3.70 & 0.694 & 3.73 & 0.679 & 3.40 & 0.700 \\
\hline Islamic cohesion & 3.68 & 1.057 & 3.70 & 0.998 & 3.34 & 1.013 \\
\hline
\end{tabular}

Since the participants in this study were from different ethnic groups of Iran and two dominant religions of the country, comparative hypotheses were designed and tested for the three variables of perception of sporting success, Islamic cohesion, and national identity between religious and ethnic groups.

\section{Comparison between religious groups}

In this study, the respondents were from two dominant religious groups, namely Shia and Sunni, so the following three hypotheses were proposed.

1. The average score of perceived sports success varies between Shiite and Sunni respondents.

2. The average score of Islamic cohesion varies between Shiite and Sunni respondents.

3. The average score of national identity varies between Shiite and Sunni respondents.

To test the above three hypotheses, a t-test with two independent samples was used. According to Table 4, we can say: The significance level of the test for the sports success perception variable is higher than 0.05 , therefore, there is no statistically significant difference between the two religious groups and the observed difference $(0.158)$ is random. But for the two variables of Islamic cohesion and national identity, the significance level of the test is less than 0.05 Therefore, there is a statistically significant difference between the two religious groups, Based on the average values, this statistical difference is in favor of the Shiite respondents. 
Table 4. T-test results with two independent samples for comparison of religious groups

\begin{tabular}{|l|l|l|l|l|l|l|}
\hline Variable & \multicolumn{2}{|l|}{ Group mean } & \multirow{2}{*}{$\mathrm{t}$} & $\begin{array}{l}\text { Freedom } \\
\text { degree }\end{array}$ & $\begin{array}{l}\text { Mean } \\
\text { difference }\end{array}$ & $\begin{array}{l}\text { Significance } \\
\text { level }\end{array}$ \\
\cline { 2 - 7 } & Shiite & Sunni & & & \\
\hline $\begin{array}{l}\text { Perception of sports } \\
\text { success }\end{array}$ & 4.40 & 4.24 & 1.94 & 949 & 0.158 & 0.053 \\
\hline Islamic cohesion & 3.73 & 3.34 & 2.93 & 949 & 0.396 & 0.003 \\
\hline National identity & 3.75 & 3.41 & 3.79 & 949 & 0.345 & 0.000 \\
\hline
\end{tabular}

\section{Comparison between ethnic groups}

In terms of ethnicity, the respondents were from the dominant ethnic groups in the country, including Turks, Persians, Kurds, Lors, Laks, Arabs, and Tat, so the following hypotheses were made.

1. The mean score of perceived athletic success varies among respondents in ethnic groups.

2. The average score of Islamic cohesion varies between the respondents of ethnic groups.

3. The average score of national identity varies between respondents of ethnic groups.

Analysis of variance (F) was used to test the above three hypotheses according to the independence status of the groups. According to the table, it can be said that the significance level of the test for the variable of perception of sports success is greater than 0.05 and the assumption of the difference between the means of ethnic groups is rejected that is, there is no statistically significant difference between ethnic groups in the perception of sports success. But for the two variables of Islamic cohesion and national identity, the significance level of the test is less than 0.05 , and the assumption of the difference between the means of ethnic groups is confirmed That is, there is a statistically significant difference between ethnic groups in the variables of Islamic cohesion and national identity, and at least in one of the groups, the average of these two variables is different from the others.

Table 5. F test results for comparison of ethnic groups

\begin{tabular}{|l|l|l|l|}
\hline Variable & F & Degrees of intergroup freedom & Significance level \\
\hline Perception of sports success & 1.85 & 7 & 0.075 \\
\hline Islamic cohesion & 6.67 & 7 & 0.000 \\
\hline National identity & 5.56 & 7 & 0.000 \\
\hline
\end{tabular}

Then, Post Hoc and Tukeys $b$ test was used to determine the quality of differences. According to Table 6, we can say: The score of Islamic cohesion is the lowest for the Tat people (3.06) and the highest for the Arabs (4.48). Also, based on the difference between the means of ethnic groups, three homogeneous groups have been formed. Homogeneous groups show that; the elements of each group do not differ in terms of the mean of the Islamic cohesion variable but they are significantly different from the average of other homogeneous groups. According to the table of the second group, ie Persian, Turkish, Kurdish, Lor, Lak, and other ethnic groups are similar in the Islamic cohesion variable, the third group, which has only the Arab people and is different from other groups in terms of Islamic cohesion. In the first group, however, there are Persians, Turks, Kurds, and Tat But only the Tat people are the exclusive element of this group, which has the lowest value in terms of the average score of Islamic cohesion.

Table 6. Results of post hoc test for Islamic cohesion variable

\begin{tabular}{|l|l|l|l|l|}
\hline nationality & \multirow{5}{|l|}{\begin{tabular}{l} 
Alpha homogeneous groups = \\
\cline { 3 - 5 }
\end{tabular}} & \multirow{2}{*}{ Frequency } & 0.05 & \\
\cline { 3 - 5 } & & 1 & 2 & 3 \\
\hline Tat & 10 & 3.06 & & \\
\hline Kord & 107 & 3.48 & 3.48 & \\
\hline Fars & 248 & 3.52 & 3.52 & \\
\hline Turkish & 268 & 3.64 & 3.64 & \\
\hline Lak & 62 & & 3.73 & \\
\hline Lor & 152 & & 3.82 & \\
\hline
\end{tabular}




\begin{tabular}{|l|l|l|l|l|}
\hline Other & 68 & & 3.84 & \\
\hline Arab & 47 & & & 4.48 \\
\hline
\end{tabular}

According to Table 7, the average of the national identity variable is the lowest (3.01) for the Arab people and the highest (3.90) for the Lak people. There are also three homogeneous groups, the first of which includes only the Arab people. The second and third groups have many elements in common. In the second group, only the Tat and Kurdish tribes are specific, which are very similar to each other and the specific ethnic groups of the third group are Turks, Persians, others, Lors, and Laks, who are similar in terms of the average score of national identity.

Table 7. Results of post hoc test for national identity variable

\begin{tabular}{|l|l|l|l|l|}
\hline \multirow{2}{*}{ nationality } & \multirow{2}{*}{ Frequency } & \multicolumn{4}{|c|}{ Alpha homogeneous groups $=0.05$} \\
\cline { 3 - 5 } & & 1 & 2 & 3 \\
\hline Arab & 47 & 3.01 & & \\
\hline Tat & 10 & & 3.53 & \\
\hline Kurd & 107 & & 3.55 & \\
\hline Turk & 268 & & 3.60 & 3.60 \\
\hline Fars & 248 & & 3.69 & 3.69 \\
\hline Others & 68 & & 3.84 & 3.84 \\
\hline lor & 152 & & 3.89 & 3.89 \\
\hline lak & 62 & & 3.90 & 3.90 \\
\hline
\end{tabular}

\section{Discussion and conclusion}

Modern sport plays an important role in people's sense of belonging to their governments, individuals as a member of a government consider sports as part of their identity, and as the success of sports increases, the sense of individual identity with collective identity increases. In addition to commemorating special events, national rituals and celebrations are also factors in furthering the sense of national identity, and sports elites are often seen as one of the basic tools for expressing national pride and fostering national cohesion for nations (Van Hilvoorde, Elling, and Stokvis2010). On the other hand, international sports competitions such as the Olympic Games, the FIFA World Cup, etc., bring together elders, athletes, and heads of state, and other national representatives, and lead to international understanding and cooperation (Jaksa, 2011). Therefore, considering the existence of different ethnic groups in Iran, it seems that strengthening national sports teams and shining in international competitions, can strengthen national solidarity and convergence and other similar elements such as social and Islamic cohesion. Therefore, in this study, hypotheses were analyzed to analyze the ethnic differences of Iranian sports fans in the variables of Islamic cohesion, national identity, and perception of sports success to determine which of these variables are more similar and close to each other.

The test showed comparative hypotheses between religious groups; the variables of Islamic cohesion and national identity between Shiite and Sunni respondents have a statistically significant difference at the error level of 0.05 , in both variables the mean of the Shiite group was higher than the Sunni group. This finding was expected due to some historical differences between Shiite and Sunni religions in the country and the fact that the national identity of Iranians is based on the official Shiite religion. The next finding showed that there is no statistically significant difference in the perception of sports success between Shiite and Sunni respondents. In other words, both religious groups in the country have a high perception of national sports achievements and do not feel any difference in this regard. Therefore, this finding emphasizes the positive functions of sports success in the convergence of more and more religious groups in the country. Few studies have pointed to this feature of sport (or sporting success), in this regard, Hashemi and Javadi Yeganeh (2007) concluded that; Iranian football can create a common religious sense even beyond national borders, in other words, the competition of the Iranian national football team in international arenas can strengthen religious solidarity among Muslim countries.

The test showed comparative hypotheses between ethnic groups; the variables of Islamic cohesion and national identity have a statistically 
significant difference between the respondents of ethnic groups at the error level of 0.05 . Due to the significant differences between the groups, the post hoc test showed that the score of Islamic cohesion was the lowest for the Tat people (3.06) and the highest for the Arabs (4.48). Also, in the Islamic cohesion variable, three homogeneous groups were formed, in which the Tat people were in the first group, the second group included the Persians, Turks, Kurds, Lors, Laks, and others (not stated), and the third group included only the Arab people. For the national identity variable, the average Arab ethnicity was the lowest (3.01) and the Lak ethnicity was the highest (3.90). In this variable, three homogeneous groups were formed, in which only the Arab people were in the first group. The second and third groups had many elements in common, in the second group only the Tat and Kurdish tribes were specific, in the third group, there were Turks, Persians, other, Lor, and Lak tribes who are similar in terms of national identity score. These findings, like the religious differences (hypotheses of the previous section), were to be expected due to the existing historical-cultural differences between the ethnic groups living in Iran. The next important finding showed that: There is no statistically significant difference in the perception of sports success between respondents of different ethnic groups, in other words, despite the differences in Islamic cohesion and national identity, different Iranian ethnic groups are more similar in terms of the perception of sporting success and there is no significant difference between them. Therefore, this finding also emphasizes the positive effects of sports success on the convergence of more and more ethnic groups in the country. There is a lot of research that has pointed to the ability of sports and sports success in strengthening elements such as national convergence, national pride, and national identity and... Ahmadi (2007) the diminishing effect of national team defeat on national identity and its inverse effect on national football team victory; Hashemi and Javadi Yeganeh (2007) The common sense of Iranians, regardless of political and factional differences, in supporting the success of the national football team; Dosti, Darvish and Khalili (2016) Nationalism of most national football team fans; Keresting (2007) Increasing German national pride during the 2006 World Cup in Germany; Hallmann, Breuer, and Quinrich (2013) Germans's sense of pride in German athletes' success at major sporting events; Elling, Van Hillward and Van den Dole (2014) Significantly increase Dutch national pride during various competitions; Erik Meier et al. (2019) The effect of a successful participation in the 2014 FIFA World Cup and the 2016 European Cup on the national pride and national belonging of the Germans; and Bravo et al. (2020) reported the national pride of most Chilean fans as the 2016 Copa America champions.

In general, the findings of the present study are interesting because it can provide valuable tips for managers and policymakers in the field of sports. Iran is a country with multiple ethnicities as well as two predominantly Shiite and Sunni religious groups. Throughout history, many events have taken place, and sometimes unpleasant memories of religious and racial confrontations have occurred in different parts of the country, all of which have acted as undermining national and religious identities. However, in many of these cases, external factors and the actions of enemies and foreign countries have been influential. Therefore, it is obvious that statistical differences in variables such as national identity and Islamic cohesion between Shiites and Sunnis should be reported in this study. But what was promising was the lack of significant differences in perceptions of sporting success between the two religious groups. In other words, the field of sports and sports achievements is a trans-religious phenomenon that has positive effects on all residents and citizens of Iran, and people, regardless of their religious affiliation, have a positive perception of sports achievements of Iranian athletes. Therefore, this finding can have valuable applications and be used as a tool to bring citizens of different religions closer together. In the comparison of different ethnic groups, as in the previous finding, Iranians, regardless of ethnicity, all have a positive perception of the sporting success of national athletes; although according to the historical background and different events have differences in national identity and Islamic cohesion. Therefore, despite some differences between different ethnic groups, sports is one of the important fields that is considered as a common chapter for all ethnic groups and can attract all citizens of a country as an attractive material. Of course, reaching this position requires continuous and appropriate efforts in this field. In a similar study, Hir et al. (2016) showed that; South Africa's hosting of the 2010 World Cup has the potential to diminish the importance of citizens' ethnic identities and make them forget ethnic differences. The findings of this study, 
while reaffirming the functions and positive social effects of sport, showed its effectiveness in the convergence and closeness of more ethnicities and religions in Iran. Sports success is one of the important results of investing in sports, and various governments are aware of this and seek to maximize their sports results. Sports and sporting successes leave positive memories and mentality in all races and religions of the country, so this capacity should be used to the maximum.

\section{References}

Abbasi Shavazi, Mohammad Jalal; Hosseini, Hatem. (2007). Ethnic differences in fertility in Iran: trends and factors affecting it, Sociology of Iran, 8th year, No. 4, 36-3. (Persian)

Ahmadi, Sirus (2007). Investigating the effects of the results of the Iranian national football team in the 2006 World Cup on the national identity of citizens (Case study of the city of Yasuj), Olympics, Volume 15, Number 1, 96-85. (Persian)

Ahmadpour, Iran; khabiri, mohammad; Rajabi, Hussein. (2017). Modeling the Role of Sports in the Process of Forming National Identity, National Studies Quarterly, Volume 18, Number 4, 58-41. (Persian)

Baghbanian, Mustafa; Marwat, Borzoo. (2011). A Survey of Students' Attitudes Towards National Unity and Islamic Cohesion in the Eleventh District of Azad University, Quarterly Journal of Sociology of Youth Studies, Second Year, No. 3, 25-25. (Persian)

Bravo, D., Oriol, X., Gómez, M., Cortez, D., \& Unanue, W. (2020). The Effects of the 2016 Copa América Centenario Victory on Social Trust, Self-Transcendent Aspirations and Evaluated Subjective Well-Being: The Role of Identity with the National Team and Collective Pride in Major Sport Events. Frontiers in Psychology, 11, 2552 .

Dosti, Morteza; Darvish, Abolfazl; Khalili, Ali Asghar. (2016). A Study of the Nationalism of the Fans of the Iranian National Football Team, Sports Management and Development, Fifth Year, No. 2, 193-176. (Persian)

Elling, A., Van Hilvoorde, I., \& Van Den Dool, R. (2014). Creating or awakening national pride through sporting success: A longitudinal study on macro effects in the Netherlands. International Review for the Sociology of Sport, 49(2), 129-151 .

Erik Meier, H., Utesch, T., Raue, C., Uhlenbrock, C., Chababi, N., \& Strauss, B. (2019). Fan identification and national identity. Sport in Society, 22(3), 476-498 .

Hajiani, Ibrahim. (2000). Sociological Analysis of National Identity in Iran and the Design of Several Hypotheses, Quarterly Journal of National Studies, Second Year, No. 5, 1928228. (Persian)

Hallmann, K., Breuer, C \& ,.Kühnreich, B. (2013). Happiness, pride and elite sporting success: What population segments gain most from national athletic achievements? Sport Management Review, 16(2), 226-235.

Heere, B., \& James, J. D. (2007). Stepping outside the lines: Developing a multi-dimensional team identity scale based on social identity theory. Sport Management Review, 10(1), 6591 .

Hashemi, Seyed Zia; Javadi Yeganeh, Mohammad Reza. (2007). Football and National Identity, National Studies Quarterly, Year 8, Issue 2, 125-107. (Persian)

Heere, B., Walker, M., Gibson, H., Thapa, B., Geldenhuys, S., \& Coetzee, W. (2016). Ethnic identity over national identity: an alternative approach to measure the effect of the World Cup on social cohesion. Journal of Sport \& Tourism, 20(1), 41-56 .

Jaksa, K. L. (2011). Sports and collective identity: The effects of athletics on national unity. SAIS Review of International Affairs, 31(1), 39-41.

Kersting, N. (2007). Sport and national identity: A Comparison of the 2006 and 2010 FIFA World Cups $^{\mathrm{TM}}$. Politikon, 34(3), 277-293.

Kiakjuri, Saeed. (2007). Factors Affecting the National Identity of Students of Payame Noor University of Shiraz, Peyk Noor, Fifth Year, No. 1, 110-97. (Persian)

Matlabi, Massoud. (2008). Political Geography of Iranian Tribes, Zamaneh, No. 70, 16-14. (Persian)

Misrabadi, Javad; Yarmohammadzadeh, Peyman; Faizi, Ayub. (2015). Determining the Dimensions of National Ethnic Identity and Comparing the Dimensions of Ethnic, 
National and Global Identity of Students of Different Ethnicities, Intercultural Studies, Volume 10, Number 25, 48-27. (Persian)

Moeidfar, Saeed; Rezaei, Alireza. (2009). An Analysis of the Situation of Ethnic Identity in Iranian Society, A Case Study of Tehran University Students, Political Studies, No. 3, 13-40. (Persian)

Mohammad Bakhsh, Bahman, Hobi, Akram, Qureshi, Fardin. (2011). Globalization and National Identity of Tabriz University Students, Social Welfare Quarterly, Eleventh Year, No. 43, 34-7. (Persian)

Van Hilvoorde, I., Elling, A., \& Stokvis, R. (2010). How to influence national pride? The Olympic medal index as a unifying narrative. International Review for the Sociology of Sport, 45(1), 87-102. Doi: 10.1177/1012690209356989

Yousefi, Ali. (2001). Inter-ethnic relations and its impact on the national identity of ethnic groups in Iran; Secondary Analysis of National Survey Data, National Studies Quarterly, Volume 2, Number 4, 13-42. (Persian)

"This article is extracted from the research plan No. 96009010 of the Iran National Science Foundation (INSF)". 